\title{
In Silico Drug Repurposing to Target Histone-Like Protein of Streptococcus Mutans
}

\author{
Shakti Chandra Vadhana Marimuthu, Joseph Christina Rosy, Esakkimuthu Thangamariappan, \\ Krishnan Sundar
}

\begin{abstract}
Streptococcus mutans, in spite of its natural occurrence in human oral cavity, causes dental caries and rarely, in some complications, infective endocarditis. Development of vaccines or drugs to prevent or control these organisms has been under study. Histone-like protein (HLP), a nucleoid associated protein, is found essential for the survival and virulence of these pathogens. We have employed an in silico approach to specifically target the HLP of Streptococcus mutans with available approved drugs from DrugBank. Computational analysis showed conserved regions in DNA-binding domain of the S. mutans HLP and its homologues in 47-49 and 78-79 residues. The $S$. mutans $H L P$ was found to be closely related within streptococcal species in phylogenetic analysis. Alanine and lysine were found to be higher in the protein which is the characteristic of histone-like proteins. The crystal structure of $S$. mutans HLP is similar to HLP from Mycobacterium tuberculosis despite their sequential variations and evolutionary distance. Etravirine, Abacavir, Adenosine phosphate, Flucloxacillin, Nelarabine, and Regadenoson were found to efficiently bind at the DNA binding domain of S. mutans HLP. From these results it can be concluded that these drugs can be repurposed to control streptococcal infections.
\end{abstract}

Keywords : AutoDock Vina, Dental caries, Histone-like proteins, infective endocarditis, Nucleoside analogues, Streptococcus mutans.

\section{INTRODUCTION}

The streptococci of viridans group are normal microflora of human oral cavity. In spite of being normal flora seldom they are pathogenic to human. Dental caries, one of the most widespread infectious diseases is caused by Streptococcus mutans [1]. The use of fluorides and dietary control has contributed to the decline in cases of dental caries and yet this has not been eradicated [2]. The viridans streptococci also cause infective endocarditis in humans [1]. Infective Endocarditis is classified into two types: acute and subacute

Revised Manuscript Received on December 16, 2019

* Correspondence Author

Shakti Chandra Vadhana Marimuthu, Department of Biotechnology, Kalasalingam Academy of Research and Education, Krishnankoil, Tamilnadu. Email: chandravadhana16@gmail.com

Joseph Christina Rosy, Department of Biotechnology, Kalasalingam Academy of Research and Education, Krishnankoil, Tamilnadu. Email: j.christinarosy@klu.ac.in

Esakkimuthu Thangamariappan, Department of Biotechnology, Kalasalingam Academy of Research and Education, Krishnankoil, Tamilnadu. Email: temlight8@gmail.com

Krishnan Sundar, Department of Biotechnology, Kalasalingam Academy of Research and Education, Krishnankoil, Tamilnadu. Email: sundarkr@klu.ac.in forms. The viridans streptococci is usually associated with subacute cases. The common symptoms of subacute form includes chills, fever, anorexia, sweats, malaise, and weight loss [3]. Among the viridans streptococci, S. mutans is the most commonly found in subacute cases [4,5]. In spite of surgical and medical developments, endocarditis causes mortality [6]. Preventive measures are restricted to antibiotic prophylaxis prior to dental surgeries that may cause bacteraemia [7]. Therefore there is a need to control dental caries and further complications such as endocarditis.

Histone-like proteins, or HLPs, are low molecular weight (16-20 kDa) DNA-binding proteins found in the prokaryotic cells [8]. HLPs are known to be involved in gene-regulation, recombination and replication. HLPs are classified into four major groups based on their amino acid sequence homology. They are, histone-like proteins from Escherichia coli U93 (HU), histone-like nucleoid structuring proteins (HNS), integration host factors (IHF), and factors for inversion stimulation (FIS). Besides, there are certain histone-like proteins that show no homology with these major groups [9]

The HLPs are also associated with virulence during infection by streptococcal species, such as S. pyogenes and others [10]. There are several mechanisms for the secretion of streptococcal HLP that still appeared to be unknown [11, 12]. The binding of streptococcal HLP to heart and kidney basement membranes was also reported and it was found to be highly immunogenic [10]. But unlike HU of E. coli, streptococcal HLP was shown to be essential for the survival of the pathogen $[13,14]$. Due to these reasons, streptococcal HLP is considered as a potential drug target. The crystal structure of apo-HLP from $\mathrm{S}$. mutans with $1.9 \mathrm{~A}^{\circ}$ resolution has been determined recently. The homodimer structure of $S$. mutans HLP (SmHLP) showed distinctive alpha-helical 'body' and two extended beta-ribbon 'arms' [15]. This discovery facilitated the further research in developing drugs that directly target SmHLP.

In the present study, a computational approach was employed to specifically target the SmHLP with available approved drugs. The SmHLP has also been analyzed for its physicochemical parameters, structural homology and phylogenetic relationship with other HLPs by using computational methods.

\section{METHODS}

\section{A. Retrieval of target protein sequence}

The protein sequence of

Published By

Blue Eyes Intelligence Engineering \& Sciences Publication 


\section{In Silico Drug Repurposing to Target Histone-Like Protein of Streptococcus Mutans}

HLP of S. mutans UA159 (UniProt id: Q9XB21) was downloaded in FASTA format from UniProtKB (http://www.uniprot.org/).

\section{B. Sequence analysis of S. mutans HLP and its homologues}

BLASTP analysis was performed in order to find the homologues of S. mutans HLP. The search was done against non-redundant protein database and Protein Data Bank. Other parameters were set default. Forty one HLP homologue sequences were selected for further analysis.

Multiple sequence alignment was performed for sequence of S. mutans HLP with all 41 sequences by using the ClustalOmega tool (https://www.ebi.ac.uk/Tools/msa /clustalo/). This tool allows the identification of conserved regions among the HLPs.

\section{Phylogenetic analysis of S. mutans HLP}

In order to study the evolutionary relationship between the HLPs, phylogenetic tree was constructed using MEGA-X software [16]. This tool provides real phylogenetic trees and cladograms for the understanding of ancestral association between the HLPs.

\section{Physiochemical properties and subcellular localization}

The physicochemical properties of S. mutans HLP such as molecular weight, theoretical pI, GRAVY (grand average of hydropathy) were predicted using ExPASy-ProtParam tool (https://web.expasy.org/protparam/). The subcellular localization of the protein was predicted by CELLO2GO web server (http://cello.life.nctu.edu.tw/cello2go/) [17].

\section{E. Retrieval of target protein structure}

The 3D structure of the S. mutans HLP (PDB Id. 5FBM) was retrieved from Protein Data Bank (https://www.rcsb.org/structure/5FBM). This structure was used for the further analysis and docking studies.

\section{F. Structure analysis of S. mutans HLP and its homologues}

The structural similarities between S. mutans HLP and nine selected homologues were performed by using the TM-align online tool (https://zhanglab.ccmb.med.umich.edu/TM-align/) [18]. This tool aligns the target protein structure with other structures and helps in the prediction of similar domains and motifs.

\section{G. Retrieval of ligand structures}

As S. mutans HLP has a DNA binding domain, the ligands for the inhibition of HLP were selected to be nucleoside analogues and were retrieved from DrugBank (https://www.drugbank.ca). Since the crystal structure of S. mutans HLP did not have any ligands to check its binding to nucleotides; the 3D structures of adenosine, guanosine, cytidine and thymidine was also retrieved.

\section{H. Molecular docking}

The target protein, S. mutans HLP, was prepared by removal of water molecules in Discovery Studio. Molecular docking was performed in AutoDock Tools platform and AutoDock Vina [19] to assess the binding efficiency of drugs to S. mutans HLP. The efficient drug was selected based on the lowest binding energy.

\section{RESULTS}

\section{A. Sequence analysis of $S$. mutans HLP and its homologues}

A total of 41 homologues of S. mutans HLP were selected for the sequence analysis (Table I).

Table- I: Homologues of S. mutans HLP

\begin{tabular}{|c|c|c|}
\hline \multicolumn{3}{|c|}{ DNA-binding protein HU/HLPs from: } \\
\hline $\begin{array}{l}\text { Alkalibacterium } \\
\text { putridalgicola }\end{array}$ & Lactobacillus gorilla & Streptococcus equi \\
\hline $\begin{array}{l}\text { Alkalibacterium } \\
\text { thalassium }\end{array}$ & $\begin{array}{l}\text { Lactobacillus } \\
\text { salivarius }\end{array}$ & $\begin{array}{l}\text { Streptococcus } \\
\text { gordonii }\end{array}$ \\
\hline $\begin{array}{l}\text { Bacillus } \\
\text { acidiproducens }\end{array}$ & $\begin{array}{l}\text { Lactococcus lactis } \\
\text { Ill } 403\end{array}$ & Streptococcus mitis \\
\hline Bacillus anthracis & $\begin{array}{l}\text { Lactococcus } \\
\text { plantarum }\end{array}$ & $\begin{array}{l}\text { Streptococcus mutans } \\
\text { UA159 }\end{array}$ \\
\hline Bacillus coagulans & Leuconostoc carnosum & Streptococcus oralis \\
\hline $\begin{array}{l}\text { Bacillus } \\
\text { ginsengihumi }\end{array}$ & $\begin{array}{l}\text { Melissococcus } \\
\text { plutonius }\end{array}$ & $\begin{array}{l}\text { Streptococcus } \\
\text { parasuis }\end{array}$ \\
\hline $\begin{array}{l}\text { Carnobacterium } \\
\text { divergens }\end{array}$ & $\begin{array}{l}\text { Mycobacterium } \\
\text { tuberculosis }\end{array}$ & $\begin{array}{l}\text { Streptococcus } \\
\text { pneumoniae }\end{array}$ \\
\hline $\begin{array}{l}\text { Domibacillus } \\
\text { epiphyticus }\end{array}$ & Oceanobacillus limi & $\begin{array}{l}\text { Streptococcus } \\
\text { pyogenes }\end{array}$ \\
\hline $\begin{array}{l}\text { Enterococcus } \\
\text { aquimarinus }\end{array}$ & $\begin{array}{l}\text { Sporosarcina } \\
\text { psychrophila }\end{array}$ & $\begin{array}{l}\text { Streptococcus } \\
\text { salivarius }\end{array}$ \\
\hline Enterococcus canis & Staphylococcus aureus & Streptococcus suis \\
\hline $\begin{array}{l}\text { Enterococcus } \\
\text { faecium }\end{array}$ & $\begin{array}{l}\text { Staphylococcus aureus } \\
\text { Mu50 }\end{array}$ & Streptococcus urinalis \\
\hline Escherichia coli & $\begin{array}{l}\text { Staphylococcus } \\
\text { epidermidis }\end{array}$ & $\begin{array}{l}\text { Thermus thermophilus } \\
\text { HB8 }\end{array}$ \\
\hline $\begin{array}{l}\text { Geobacillus } \\
\text { stearothermophilus }\end{array}$ & $\begin{array}{l}\text { Staphylococcus } \\
\text { pasteuri }\end{array}$ & Vagococcus penaei \\
\hline Lactobacillus agilis & $\begin{array}{l}\text { Streptococcus } \\
\text { agalactiae }\end{array}$ & Weissella viridescens \\
\hline
\end{tabular}

In Clustal Omega, 41 homologue proteins were aligned with SmHLP. The conserved region among the HLPs was observed in 47-49 position containing glycine, phenylalanine and glycine and in 78-79 positions containing proline, alanine and phenylalanine (data not shown). This region is DNA-binding domain of the HLPs and hence shows its significance.

\section{B. Phylogenetic analysis of S. mutans HLP}

The cladogram (Figure 1) generated by MEGA-X software showed the evolutionary relationship between the HLPs. The protein sequence of HLP was found to be conserved within closely related streptococcal species. 


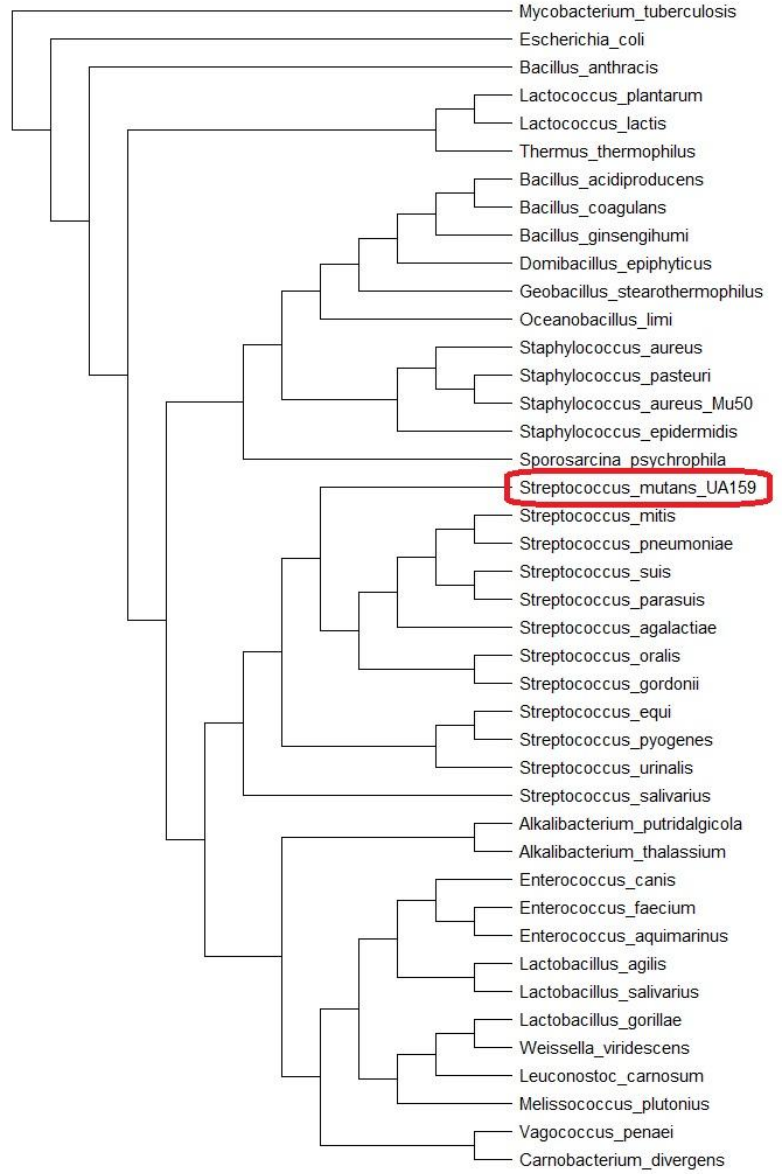

Fig. 1. The cladogram shows that S. mutans HLP is closely related to organisms within the same genus

\section{Physiochemical properties and subcellular localization}

ExPASy ProtParam provided the amino acid composition (data not shown) and physicochemical properties (Table II) of SmHLP.

Table- II: Physicochemical parameters of S. mutans HLP

\begin{tabular}{|l|r|}
\hline \multicolumn{2}{|c|}{ Physiochemical properties of S. mutans HLP } \\
\hline Number of amino acids & 91 \\
\hline Molecular weight & 9706.23 \\
\hline Theoretical Pi & 9.82 \\
\hline Total number of negatively charged residues (Asp + Glu) & 11 \\
\hline Total number of positively charged residues (Arg + Lys) & $1490 \mathrm{M}^{-1} \mathrm{~cm}^{-1}$ \\
\hline Extinction coefficients & $30 \mathrm{hours}^{-1}$ \\
\hline Estimated half-life (mammalian reticulocytes, in vitro) & $>20 \mathrm{hours}^{-1}$ \\
\hline Estimated half-life (yeast, in vivo) & $>10$ hours \\
\hline Estimated half-life (Escherichia coli, in vivo) & 19.88 (Stable) \\
\hline Instability index & 82.75 \\
\hline Aliphatic index & -0.338 \\
\hline Grand average of hydropathicity (GRAVY) & \\
\hline
\end{tabular}

Published By

Alanine and lysine were found to be higher in the protein whereas there was absence of cysteine, histidine, tryptophan, pyrrolysine or selenocysteine. The localization of the protein was predicted to be in the cytoplasmic region by CELLO2GO web server and the molecular function was also predicted to be DNA-binding (Figure 2).

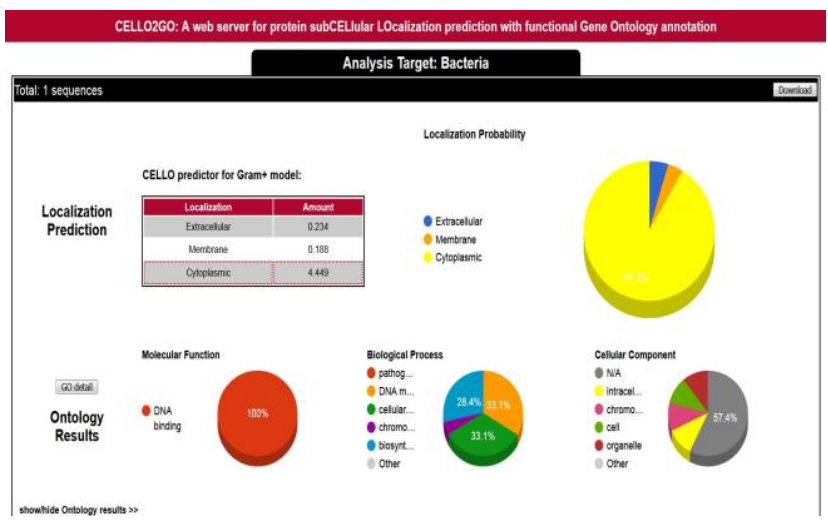

Fig. 2. Prediction of subcellular localization and gene ontology of SmHLP by CELLO2GO

\section{Structure analysis of S. mutans HLP and its homologues}

The structure of 9 HLPs from Staphylococcus aureus Mu50, Lactococcus lactis Il1403, Geobacillus stearothermophilus, Bacillus anthracis, Escherichia coli, Thermus thermophilus HB8, and Mycobacterium tuberculosis were aligned with SmHLP using the TM-align online tool. Based on RMSD value, the structure of HLP from L. lactis Il1403, E. coli and M. tuberculosis were found to be aligned best with SmHLP (data not shown).

The crystal structure of HLP from L. lactis I11403 is a complex of two HLPs and hence the SmHLP aligned with one of the domains; whereas HLPs from E. coli and $\mathrm{M}$. tuberculosis aligned completely with SmHLP (Figure 3A-C).
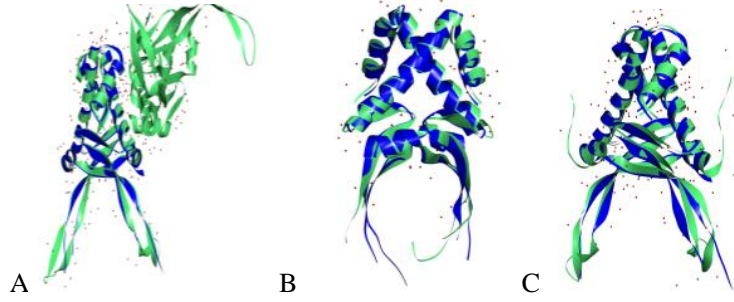

Fig. 3. Structure alignment of S. mutans HLP with that of L. lactis Il1403 (A) E. coli (B) and M. tuberculosis (C) in TM-align tool

\section{E. Retrieval of ligand structures}

The 3D structures of adenosine, guanosine, cytidine, thymidine, and 38 nucleoside analogues were retrieved. The selected nucleoside analogues were all approved drugs used in various diseases (Table III). 
In Silico Drug Repurposing to Target Histone-Like Protein of Streptococcus Mutans

Table- III: List of approved nucleoside analogue drugs from DrugBank and their known targets

\begin{tabular}{|l|l|l|l|}
\hline $\begin{array}{c}\text { DrugBank } \\
\text { Accession } \\
\text { No. }\end{array}$ & Drug Name & $\begin{array}{c}\text { DrugBank } \\
\text { Accession } \\
\text { No. }\end{array}$ & Drug Name \\
\hline DB01048 & Abacavir & DB00249 & Idoxuridine \\
\hline DB00787 & Acyclovir & DB01064 & Isoprenaline \\
\hline DB00718 & Adefovir dipivoxil & DB00709 & Lamivudine \\
\hline DB00640 & Adenosine & DB00583 & Levocarnitine \\
\hline DB00131 & $\begin{array}{l}\text { Adenosine } \\
\text { phosphate }\end{array}$ & DB01280 & Nelarabine \\
\hline DB00928 & Azacitidine & DB00238 & Nevirapine \\
\hline DB00369 & Cidofovir & DB00299 & Penciclovir \\
\hline DB00631 & Clofarabine & DB06213 & Regadenoson \\
\hline DB00987 & Cytarabine & DB00811 & Ribavirin \\
\hline DB02097 & Cytidine & DB08934 & Sofosbuvir \\
\hline DB00900 & Didanosine & DB00649 & Stavudine \\
\hline DB00879 & Emtricitabine & DB01265 & Telbivudine \\
\hline DB00442 & Entecavir & DB14126 & Tenofovir \\
\hline DB06414 & Etravirine & DB09299 & $\begin{array}{l}\text { Tenofovir } \\
\text { alafenamide }\end{array}$ \\
\hline DB00426 & Famciclovir & DB00300 & $\begin{array}{l}\text { Tenofovir } \\
\text { disoproxil }\end{array}$ \\
\hline DB00301 & Flucloxacillin & DB11155 & Triclocarban \\
\hline DB01099 & Flucytosine & DB00432 & Trifluridine \\
\hline DB00544 & Fluorouracil & DB04485 & Thymidine \\
\hline DB01004 & Ganciclovir & DB01610 & Valganciclovir \\
\hline DB00441 & Gemcitabine & DB00943 & Zalcitabine \\
\hline DB02857 & Guanosine & DB00495 & Zidovudine \\
\hline
\end{tabular}

\section{F. Molecular Docking}

Among the 38 drugs, etravirine was found to efficiently bind with the target protein, SmHLP, based on its lowest binding energy. Abacavir, adenosine phosphate, flucloxacillin, nelarabine and regadenoson also bind to SmHLP with lower binding energy compared to basic nucleotides (Table IV).

Table- IV: List of Best Binders among nucleoside analogues, their binding energy, number of hydrogen bonds and interacting amino acids.

\begin{tabular}{|l|c|c|l|}
\hline \multicolumn{1}{|c|}{$\begin{array}{c}\text { Drug } \\
\text { Name }\end{array}$} & $\begin{array}{c}\text { Binding } \\
\text { energy } \\
\text { (Kcal/mo } \\
\text { l) }\end{array}$ & $\begin{array}{c}\text { Hydrogen } \\
\text { bonds }\end{array}$ & Interacting Amino acids \\
\hline Abacavir & $\mathbf{- 5 . 6}$ & $\mathbf{6}$ & $\begin{array}{l}\text { PHE30; SER31; SER34; } \\
\text { ALA85; ASP88; ALA89 }\end{array}$ \\
\hline Acyclovir & -4.1 & 5 & $\begin{array}{l}\text { LYS4; ASP27; SER35; } \\
\text { GLY47 }\end{array}$ \\
\hline $\begin{array}{l}\text { Adefovir_di } \\
\text { pivoxil }\end{array}$ & -4.7 & 4 & $\begin{array}{l}\text { LYS10; ALA14; ALA28; } \\
\text { SER31; ALA32; SER35 }\end{array}$ \\
\hline Adenosine & -5.3 & 4 & $\begin{array}{l}\text { ARG56; LYS73; SER75; } \\
\text { LYS87; ASP88; LYS91 }\end{array}$ \\
\hline $\begin{array}{l}\text { Adenosine_ } \\
\text { phosphate }\end{array}$ & $\mathbf{- 5 . 4}$ & $\mathbf{7}$ & $\begin{array}{l}\text { ARG56; ALA79; ALA79; } \\
\text { PHE80; LYS81; ALA82; } \\
\text { LYS87 }\end{array}$ \\
\hline
\end{tabular}

\begin{tabular}{|c|c|c|c|}
\hline Azacitidine & -4.5 & 6 & $\begin{array}{l}\text { ILE46; GLY47; GLY49; } \\
\text { LYS81; GLY83; ALA85 }\end{array}$ \\
\hline Cidofovir & -4.7 & 11 & $\begin{array}{l}\text { LYS42; GLN44; LEU45; } \\
\text { ILE46; GLY47; PHE48; } \\
\text { ASN50; LYS81; ALA82; } \\
\text { ALA85 }\end{array}$ \\
\hline Clofarabine & -4.5 & 2 & $\begin{array}{l}\text { GLN44; ASN50; LYS81; } \\
\text { LYS84; LYS87 }\end{array}$ \\
\hline Cytarabine & -4.7 & 5 & $\begin{array}{l}\text { ARG54; PRO78; ALA79; } \\
\text { PHE80; PHE80; LYS87 }\end{array}$ \\
\hline Cytidine & -5.2 & 8 & $\begin{array}{l}\text { ARG54; ARG56; ALA79; } \\
\text { PHE80; PHE80; LYS87 }\end{array}$ \\
\hline Didanosine & -4.7 & 1 & $\begin{array}{l}\text { ARG54; VAL77; LYS87; } \\
\text { LYS91 }\end{array}$ \\
\hline $\begin{array}{l}\text { Emtricitabin } \\
\mathrm{e}\end{array}$ & -3.6 & 1 & VAL77; LYS87 \\
\hline Entecavir & -4.5 & 3 & $\begin{array}{l}\text { VAL77; ALA79; ALA79; } \\
\text { PHE80; LYS87; }\end{array}$ \\
\hline Etravirine & -6 & 1 & ILE72; VAL77; PHE80 \\
\hline Famciclovir & -4.2 & 4 & $\begin{array}{l}\text { GLN44; LEU45; ILE46; } \\
\text { PHE48; GLY83; LYS84 }\end{array}$ \\
\hline $\begin{array}{l}\text { Flucloxacilli } \\
\text { n }\end{array}$ & -5.6 & 5 & $\begin{array}{l}\text { ARG54; VAL77; ALA79, } \\
\text { LYS81; ALA82; LYS87 }\end{array}$ \\
\hline Flucytosine & -3.7 & 5 & $\begin{array}{l}\text { ARG54; ALA79; PHE80; } \\
\text { PHE80 }\end{array}$ \\
\hline Fluorouracil & -3.9 & 5 & $\begin{array}{l}\text { VAL77; ALA79; PHE80; } \\
\text { LYS81; ALA82; LYS87 }\end{array}$ \\
\hline Ganciclovir & -4.7 & 6 & $\begin{array}{l}\text { ARG54; ALA79; PHE80; } \\
\text { LYS81; LYS87 }\end{array}$ \\
\hline Gemcitabine & -5.2 & 7 & $\begin{array}{l}\text { ARG54; ARG56; PHE80; } \\
\text { PHE80; LYS81; LYS87 }\end{array}$ \\
\hline Guanosine & -5.3 & 5 & $\begin{array}{l}\text { ARG56; ALA57; VAL77; } \\
\text { ALA79; PHE80; ALA82; } \\
\text { LYS87 }\end{array}$ \\
\hline Idoxuridine & -5.1 & 7 & $\begin{array}{l}\text { ARG56; ARG59; LYS73; } \\
\text { SER75; LYS87; ASP88; } \\
\text { LYS91 }\end{array}$ \\
\hline Isoprenaline & -3.9 & 3 & ILE46; LYS84; ALA85; \\
\hline Lamivudine & -4.5 & 3 & ARG54; ALA79; LYS81 \\
\hline $\begin{array}{l}\text { Levocarnitin } \\
\mathrm{e}\end{array}$ & -3.7 & 5 & $\begin{array}{l}\text { ARG56; ARG59; SER75; } \\
\text { ASP88 }\end{array}$ \\
\hline Nelarabine & -5.6 & 4 & $\begin{array}{l}\text { ARG54; ARG56; ALA79; } \\
\text { ALA79; LYS87 }\end{array}$ \\
\hline Nevirapine & -4.5 & - & $\begin{array}{l}\text { ARG54; VAL77; ALA79; } \\
\text { ALA79; LYS81 }\end{array}$ \\
\hline Penciclovir & -3.7 & 2 & $\begin{array}{l}\text { ALA9; LYS10; ALA12; } \\
\text { LYS19 }\end{array}$ \\
\hline $\begin{array}{l}\text { Regadenoso } \\
\text { n }\end{array}$ & -5.9 & 6 & $\begin{array}{l}\text { ARG56; PRO78; ALA79; } \\
\text { PHE80; LYS81; ALA82; } \\
\text { LYS87 }\end{array}$ \\
\hline Ribavirin & -4.9 & 4 & $\begin{array}{l}\text { VAL77; PHE80; PHY80; } \\
\text { ALA82; LYS87 }\end{array}$ \\
\hline Sofosbuvir & -4.8 & 5 & $\begin{array}{l}\text { ARG59; ILE72; PRO78; } \\
\text { PHY80; LYS81; LYS87 }\end{array}$ \\
\hline Stavudine & -4.6 & 4 & $\begin{array}{l}\text { VAL77; ALA79; PHE80; } \\
\text { ALA82; LYS87 }\end{array}$ \\
\hline Telbivudine & -4.7 & - & ARG54; ALA79 \\
\hline Tenofovir & -4.3 & 2 & $\begin{array}{l}\text { ILE46; PHE48; ASN50; } \\
\text { GLU52; LYS84; ALA85; }\end{array}$ \\
\hline $\begin{array}{l}\text { Tenofovir_al } \\
\text { afenamide }\end{array}$ & -5.2 & 5 & $\begin{array}{l}\text { LYS42; GLU52; LYS81; } \\
\text { LYS84; LYS87 }\end{array}$ \\
\hline $\begin{array}{l}\text { Tenofovir_d } \\
\text { isoproxil }\end{array}$ & -5 & 8 & $\begin{array}{l}\text { GLN44; ILE46; ASN50; } \\
\text { LYS81; ALA82; LYS84; } \\
\text { ALA85; LYS87 }\end{array}$ \\
\hline Triclocarban & -5.1 & 3 & ILE46; LYS84; ALA85; \\
\hline Trifluridine & -5.1 & 8 & $\begin{array}{l}\text { LEU45; GLY47; PHE48; } \\
\text { GLY49; GLY83; LYS84; } \\
\text { LYS87 }\end{array}$ \\
\hline Thymidine & -4.8 & 6 & $\begin{array}{l}\text { LEU45; GLY47; PHE48; } \\
\text { ASN50; LYS81; GLY83; } \\
\text { LYS84 }\end{array}$ \\
\hline $\begin{array}{l}\text { Valganciclo } \\
\text { vir }\end{array}$ & -4.4 & 6 & $\begin{array}{l}\text { GLN44; LEU45; ASN50; } \\
\text { LYS84 }\end{array}$ \\
\hline Zalcitabine & -4.7 & 4 & $\begin{array}{l}\text { ARG54; ALA79; PHE80; } \\
\text { LYS87 }\end{array}$ \\
\hline
\end{tabular}

Published By: 
These drugs were also found to interact with SmHLP at the DNA-binding domain and the binding site was found to overlap with that of basic nucleotides (Figure 9: a-f).
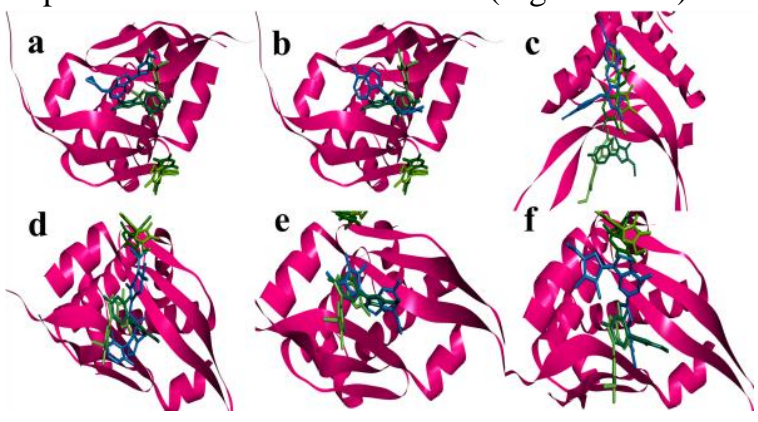

Fig. 4. Overlapping of top hit compounds (blue), a) Abacavir, b) Adenosine phosphate, c) Etravirine, d) Flucloxacillin, e) Nelarabine, and f) Regadenoson, with the binding pose of nucleotides (green) with $\mathrm{S}$. mutans HLP (magenta).

\section{DISCUSSION}

Dental caries and periodontitis are considered as major oral diseases and several sstudies have shown the association of periodontitis with cardiovascular diseases [20, 21]. Therefore, many researchers focus on the detection of periodontitis associated bacterial pathogens in cardiovascular specimens [22-24]. But the oxidative conditions of bloodstream benefit the survival of oral streptococci rather than other obligate anaerobic pathogens of periodontitis. Few sstudies have indicated the presence of S. mutans in cardiovascular specimens [25-26].

The nucleoid-associated proteins (NAPs) regulate important functions like DNA bending, supercoiling and DNA compaction in prokaryotes. Apart from these architectural functions, certain NAPs also regulate DNA replication, repair, and transcription. Though many NAPs are expressed by bacteria, some of them are essential for their survival. HLPs are one such essential NAPs produced by S. mutans. The essentiality of streptococcal HLPs for survival makes it an ideal target for the development of drug for controlling streptococcal infections [15].

Computational methods are faster way to study the inhibition of target proteins that cause certain diseases. Multiple sequence analysis of 41 HLPs from different organisms shows conserved region among them. The position of these conserved regions was found to be in DNA-binding domain of the HLP. The phylogenetic analysis of SmHLP showed that it is closely related within streptococcal species. It was long ago diverged from $\mathrm{M}$. tuberculosis, E. coli. The protein was predicted to be non-polar based on its negative GRAVY score. The highest number of alanine residues may contribute to the non-polar nature of the protein.

One of the studies on crystallization of S. mutans HLP has compared it to HLP from M. tuberculosis called Mtb HU (15). In spite of evolutionary divergence based on sequence, SmHLP is structurally similar to HLP from M. tuberculosis. Researchers have identified targetable core region inside the HU-DNA interface. Stilbene derivatives have been used to precisely inhibit binding of $\mathrm{HU}$ to DNA, consequently disturbing nucleoid architecture and diminish the growth of M. tuberculosis. These small molecule inhibitors induce gene expression modifications in Mycobacterium similar to changes induced by HU deficiency [27]. As the SmHLP is a DNA-binding protein, we have selected drugs, which are nucleoside analogues, as inhibitory compounds. The SmHLP retrieved from PDB was in its apo-form and hence for comparison with standard ligands i.e. natural nucleotides were used. Molecular docking facilitates the assessment of binding energies between ligand and a target protein in $\mathrm{Kcal} / \mathrm{mol}$.

AutoDock Vina has been used to analyze the binding efficacy of pyridochromanone and adenosine-derived inhibitors to putative drug targets in Tropheryma whipplei [28]. Etravirine, abacavir, adenosine phosphate, flucloxacillin, nelarabine, and regadenoson were found to efficiently bind to SmHLP. Their interaction with DNA-binding domain of SmHLP overlaps the binding position of basic nucleotides in same residues. This result indicates that these drugs may interfere with the DNA-binding ability of HLP. This makes them probably good drugs against streptococcal infections. Further in vitro studies are still required to confirm the inhibition efficiency of the drugs and control of streptococcal infections.

\section{REFERENCES}

1. C. Munro and F. L. Macrina, "Molecular pathogenesis of viridans streptococcal endocarditis." In: C.I. Kado, J. H. Crosa (Eds) "Molecular Mechanisms of Bacterial Virulence," vol. 3. Springer: Dordrecht, 1994, pp. 249-265.

2. T. Koga, T. Oho, Y. Shimazaki, and Y. Nakano, "Immunization against dental caries," Vaccine, vol. 20(16), pp. 2027-44, May 2002.

3. K. Nakano, R. Nomura, and T. Ooshima, "Streptococcus mutans and cardiovascular diseases,” Jpn. Dent. Sci. Rev., vol. 44(1), pp. 29-37, July 2008.

4. V. Gauduchon, Y. Benito, M. Celard, C. Mouren, V. Delorme, J. Philippe-Bert, J. Etienne, and F. Vandenesch, "Molecular diagnosis of recurrent Streptococcus mutans endocarditis by PCR amplification and sequencing," Clin. Microbiol. Infect., vol. 7(1), pp. 36-7, January 2001.

5. R. Nomura, K. Nakano, H. Nemoto, K. Fujita, S. Inagaki, T. Takahashi, K. Taniguchi, M. Takeda, H. Yoshioka, A. Amano, and T. Ooshima, "Isolation and characterization of Streptococcus mutans in heart valve and dental plaque specimens from a patient with infective endocarditis," J. Med. Microbiol., vol. 55(8), 1135-40, August 2006.

6. D. T. Durack, "Prevention of infective endocarditis," N. Engl. J. Med., vol. 332(1), pp. 38-44, January 1995.

7. A. S. Dajani, K. A. Taubert, W. Wilson, A. F. Bolger, A. Bayer, P. Ferrieri, M. H. Gewitz, S. T. Shulman, S. Nouri, J. W. Newburger, and C. Hutto, "Prevention of bacterial endocarditis: recommendations by the American Heart Association," Circulation, vol. 96(1), pp. 358-66, July 1997.

8. M. Thanbichler, S. C. Wang, and L. Shapiro, "The bacterial nucleoid: a highly organized and dynamic structure,” J. Cell. Biochem., vol. 96(3), pp. 506-21, October 2005.

9. K. A. Drlica and J. O. Rouviere-Yaniv, "Histone-like proteins of bacteria" Microbiological Microbiol. Rev., vol. 51(3), pp. 301, September 1987.

10. B. D. Winters, N. A. Ramasubbu, and M. W. Stinson, "Isolation and 


\section{In Silico Drug Repurposing to Target Histone-Like Protein of Streptococcus Mutans}

characterization of a Streptococcus pyogenes protein that binds to basal laminae of human cardiac muscle," Infect. Immun., vol. 61(8), pp 3259-64, August 1993.

11. D. Liu, H. Yumoto, K. Hirota, K. Murakami, K. Takahashi, K. Hirao, T. Matsuo, K. Ohkura, H. Nagamune, and Y. Miyake, "Histone-like DNA binding protein of Streptococcus intermedius induces the expression of pro-inflammatory cytokines in human monocytes via activation of ERK1/2 and JNK pathways," Cell. Microbiol., vol. 10(1), pp. 262-76, January 2008.

12. A. Boleij, R. M. Schaeps, S. de Kleijn, P. W. Hermans, P. Glaser, V. Pancholi, D. W. Swinkels, and H. Tjalsma, "Surface-exposed histone-like protein a modulates adherence of Streptococcus gallolyticus to colon adenocarcinoma cells," Infect. Immun., vol. 77(12), pp. 5519-27, December 2009.

13. D. Liu, H. Yumoto, K. Murakami, K. Hirota, T. Ono, H. Nagamune, S. Kayama, T. Matsuo, and Y. Miyake, "The essentiality and involvement of Streptococcus intermedius histone-like DNA-binding protein in bacterial viability and normal growth," Mol. Microbiol., vol. 68(5), pp. 1268-82, June 2008.

14. I. Biswas, and S. S. Mohapatra, "CovR alleviates transcriptional silencing by a nucleoid-associated histone-like protein in Streptococcus mutans," J. Bacteriol., vol. 194(8), pp. 2050-61, April 2012.

15. P. O'Neil, S. Lovell, N. Mehzabeen, K. Battaile, and I. Biswas, "Crystal structure of histone-like protein from Streptococcus mutans refined to 1.9 $\AA$ resolution,” Acta Crystallogr., Sect. F: Struct. Biol. Commun., vol. 72(4), pp. 257-62, April 2016.

16. S. Kumar, G. Stecher, M. Li, C. Knyaz, and K. Tamura, "MEGA X: molecular evolutionary genetics analysis across computing platforms," Mol. Biol. Evol., vol. 35(6), pp. 1547-9, May 2018.

17. C. S. Yu, C. W. Cheng, W. C. Su, K. C. Chang, S. W. Huang, J. K. Hwang, and C. H. Lu, "CELLO2GO: a web server for protein subCELlular LOcalization prediction with functional gene ontology annotation," PloS one, vol. 9(6), pp. e99368, June 2014.

18. Y. Zhang, and J. Skolnick, "TM-align: a protein structure alignment algorithm based on the TM-score," Nucleic Acids Res., vol. 33(7), pp. 2302-9, January 2005.

19. O. Trott, and A. J. Olson, "AutoDock Vina: improving the speed and accuracy of docking with a new scoring function, efficient optimization, and multithreading," J. Comput. Chem., vol. 31(2), pp. 455-61, January 2010.

20. F. A. Scannapieco, R. B. Bush, and S. Paju, "Associations between periodontal disease and risk for atherosclerosis, cardiovascular disease, and stroke. A systematic review," Ann. Periodontol., vol. 8(1), pp. 38-53, December 2003.

21. B. L. Pihlstrom, B. S. Michalowicz, and N. W. Johnson, "Periodontal diseases," Lancet, vol. 366(9499), pp. 1809-20, November 2005.

22. B. Chiu, "Multiple infections in carotid atherosclerotic plaques," Am. Heart J., vol. 138(5), pp. S534-6, November 1999.

23. V. I. Haraszthy, J. J. Zambon, M. Trevisan, M. Zeid, and R. J. Genco, "Identification of periodontal pathogens in atheromatous plaques," J. Periodontol., vol. 71(10), pp. 1554-60, October 2000.

24. K. Okuda, K. Ishihara, T. Nakagawa, A. Hirayama. Y. Inayama, and K. Okuda, "Detection of Treponema denticola in atherosclerotic lesions," J. Clin. Microbiol., vol. 39(3), pp. 1114-7, March 2001

25. K. Nakano, H. Inaba, R. Nomura, H. Nemoto, M. Takeda, H. Yoshioka, H. Matsue, T. Takahashi, K. Taniguchi, A. Amano, and T. Ooshima, "Detection of cariogenic Streptococcus mutans in extirpated heart valve and atheromatous plaque specimens," J. Clin. Microbiol., vol. 44(9), pp. 3313-7, September 2006.

26. E. Kozarov, D. Sweier, C. Shelburne, A. Progulske-Fox, and D. Lopatin "Detection of bacterial DNA in atheromatous plaques by quantitative PCR,” Microbes Infect., vol. 8(3), pp. 687-93, March 2006.

27. T. Bhowmick, S. Ghosh, K. Dixit, V. Ganesan, U. A. Ramagopa, D. Dey, S. P. Sarma, S. Ramakumar, and V. Nagaraja, "Targeting Mycobacterium tuberculosis nucleoid-associated protein HU with structure-based inhibitors," Nat. Commun., vol. 5, pp. 4124, June 2014.

28. N. Palanisamy, "Identification of putative drug targets and annotation of unknown proteins in Tropheryma whipplei," Comput. Biol. Chem., vol. 76, pp. 130-8, October 2018 .

\section{AUTHORS PROFILE}

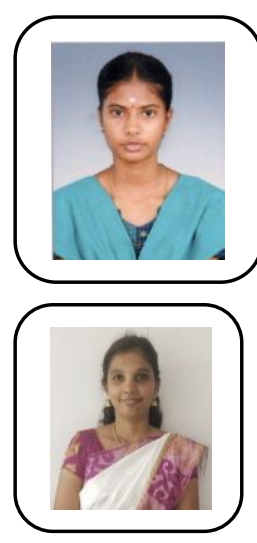

Shakti Chandra Vadhana Marimuthu graduated with a Master's degree in Microbiology and is currently a Research Fellow in the Department of Biotechnology, Kalasalingam Academy of Research and Education, working in the field of infectious diseases. Her current work focuses on quorum sensing and iron sequestration mechanisms in gram positive oral pathogen, Streptococcus mutans.

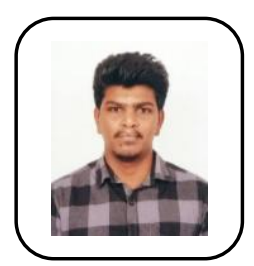

Christina Rosy, Joseph is currently working as an Assistant Professor in the Department of Biotechnology, Kalasalingam Academy of Research and Education. She has completed her Masters' in Biotechnology and pursuing $\mathrm{PhD}$ on 'Iron and Virulence'.

Esakkimuthu Thangamariappan did his Master's degree in Biotechnology from Alagappa University and is currently a Junior Research Fellow in the Department of Biotechnology, Kalasalingam Academy of Research and Education. He is working in the field of Immunology and infectious diseases. His current work focuses on developing novel platforms for vaccine delivery.

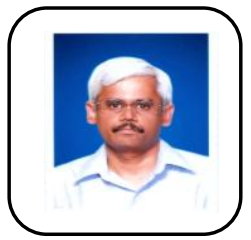

Dr Krishnan Sundar is a Professor of Biotechnology at Kalasalingam Academy of Research and Education. He received his Ph.D. degree in Microbiology from Madurai Kamaraj University. His research interests include target identification and drug design using in silico tools. 